Invited review

\title{
Purinergic mechanisms in neuroinflammation: An update from molecules to behavior
}

\author{
Edward Beamer, Flóra Gölöncsér, Gergely Horváth, Katinka Bekő, Lilla Otrokocsi, \\ Bence Koványi, Beáta Sperlágh*
}

Laboratory of Molecular Pharmacology, Institute of Experimental Medicine, Hungarian Academy of Sciences, H-1450 Budapest, Hungary

\section{A R T I C L E I N F O}

\section{Article history:}

Received 30 July 2015

Received in revised form

11 September 2015

Accepted 14 September 2015

Available online $\mathrm{xxx}$

\section{Keywords:}

Neuroinflammation

NLRP3 inflammasome

Cytokines

P2X receptor

P2Y receptor

P1 receptor

\begin{abstract}
A B S T R A C T
The principle functions of neuroinflammation are to limit tissue damage and promote tissue repair in response to pathogens or injury. While neuroinflammation has utility, pathophysiological inflammatory responses, to some extent, underlie almost all neuropathology. Understanding the mechanisms that control the three stages of inflammation (initiation, propagation and resolution) is therefore of critical importance for developing treatments for diseases of the central nervous system. The purinergic signaling system, involving adenosine, ATP and other purines, plus a host of P1 and P2 receptor subtypes, controls inflammatory responses in complex ways. Activation of the inflammasome, leading to release of pro-inflammatory cytokines, activation and migration of microglia and altered astroglial function are key regulators of the neuroinflammatory response. Here, we review the role of P1 and P2 receptors in mediating these processes and examine their contribution to disorders of the nervous system. Firstly, we give an overview of the concept of neuroinflammation. We then discuss the contribution of P2X, P2Y and $\mathrm{P} 1$ receptors to the underlying processes, including a discussion of cross-talk between these different pathways. Finally, we give an overview of the current understanding of purinergic contributions to neuroinflammation in the context of specific disorders of the central nervous system, with special emphasis on neuropsychiatric disorders, characterized by chronic low grade inflammation or maternal inflammation. An understanding of the important purinergic contribution to neuroinflammation underlying neuropathology is likely to be a necessary step towards the development of effective interventions.
\end{abstract}

(c) 2015 Elsevier Ltd. All rights reserved.

\section{Contents}

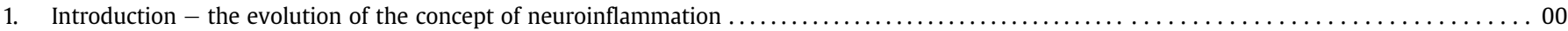

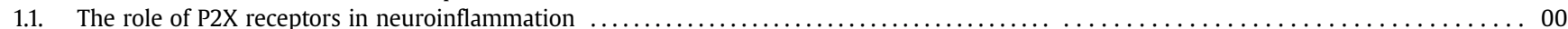

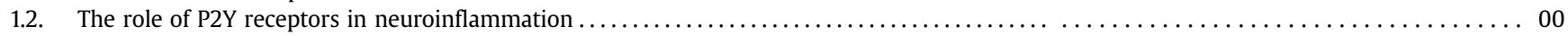

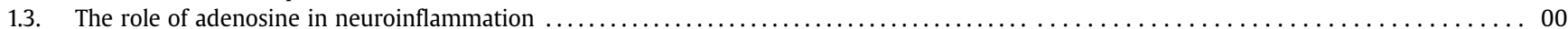

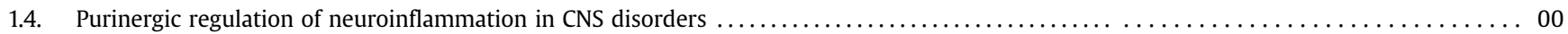

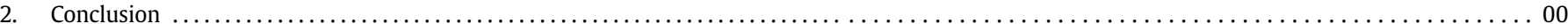

Abbreviations: ASC, apoptosis-associated speck-like protein; AD, Alzheimer's disease; ALS, amyotrophic lateral sclerosis; BD, bipolar disorder; BBB, blood brain barrier;

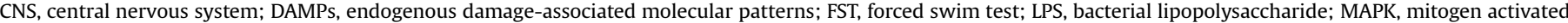

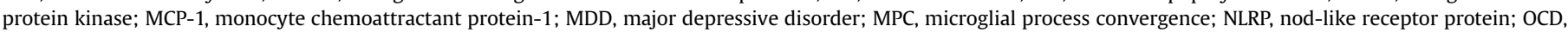

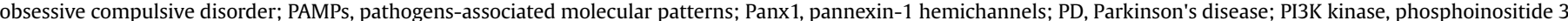

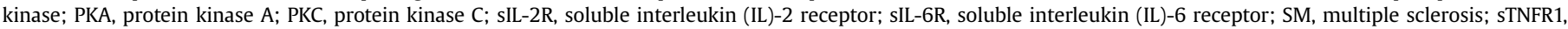
soluble tumor necrosis factor receptor type 1; TLRs, toll-like receptors; TNF- $\alpha$, tumor necrosis factor- $\alpha$; TST, tail suspension test.

* Corresponding author. Department of Pharmacology, Institute of Experimental Medicine, Hungarian Academy of Sciences, H-1083 Budapest, Szigony u. 43, Hungary.

E-mail address: sperlagh@koki.hu (B. Sperlágh). 


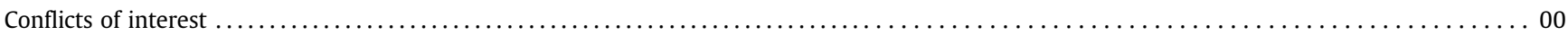

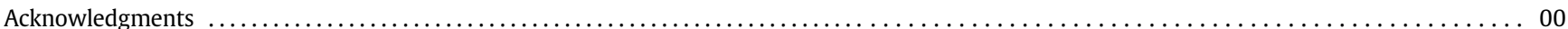

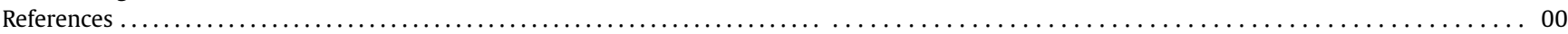

\section{Introduction - the evolution of the concept of neuroinflammation}

The term 'inflammation' was coined by Celsus around the 1st century BC, defined by four cardinal signs; tumor, rubor, calor and dolor (Celsus, 1478) (i.e. oedema, redness, increased temperature and pain in the affected tissue) with a fifth sign, loss of function, attributed to Galen. By the identification of underlying molecular and cellular mechanisms, inflammation now assumes a substantially wider meaning, as a complex biological response to harmful stimuli, composed of three phases: initiation, propagation and resolution (Lister et al., 2007). While the principle functions of inflammation are to limit tissue damage and promote tissue repair (Nathan, 2002), inappropriate inflammatory responses, particularly when chronic, can lead to toxicity and cell loss (Hauss-Wegrzyniak et al., 2002).

The central nervous system (CNS), separated from the periphery by a specialized blood brain barrier (BBB) has long been considered an 'immuno-privileged' region (Carson et al., 2006), protected from systemic immune and inflammatory responses to pathology or injury. Behind the protection of the BBB, however, CNS-specific immune effector cells, particularly microglia (Streit et al., 2004), mediate neuroinflammatory responses to insult in response to a variety of triggers, including toxic metabolites, autoimmunity (Gendelman, 2002) or via the detection of pathogens or endogenous damage-associated molecular patterns (PAMPs and DAMPs) released in response to CNS damage, such as traumatic brain injury (Bernier, 2012). The outcome of a neuroinflammatory response depends, to a large extent, on its severity and duration (Vivekanantham et al., 2015), but pathological neuroinflammation, promoting apoptosis and necrosis and influencing the synaptic and intrinsic membrane properties of neurons (Yirmiya and Goshen, 2011), contributes to a host of CNS pathologies. A central role for neuroinflammation has been reported for primary or secondary neurodegenerative diseases, such as Alzheimer's disease (AD), Parkinson's disease (PD), multiple sclerosis (SM) amyotrophic lateral sclerosis (ALS), Huntington's disease, stroke and epilepsy (Frank-Cannon et al., 2009). Neuroinflammation has also been recognized as a pathological factor in psychiatric mood disorders, characterized by chronic mild neuroinflammation (Najjar et al., 2013), and developmental neuropsychiatric disorders, such as schizophrenia and autism (Meyer, 2013).

The main cellular effectors of neuroinflammation are astrocytes and microglia, as well as perivascular monocytes and macrophages invading to sites of insult from the circulation (Yamasaki et al., 2014). In addition, neurogenic neuroinflammation, the direct contribution of neuronal activity, is a unique feature of the nervous system (Xanthos and Sandkuhler, 2014). Chronic neuroinflammation involves the sustained activation of glial cells, chronic release of pro-inflammatory cytokines, increased permeability of the $\mathrm{BBB}$ and recruitment of systemic immune effector cells into the CNS (O'Callaghan et al., 2008).

Neuroinflammatory cascades rely on the activation of an inflammasome, a protein complex, consisting of caspase-1, apoptosis-associated speck-like protein (ASC) and nod-like receptor protein (NLRP1 or NLRP3) (Martinon et al., 2002). The inflammasome is the principle source of mature proinflammatory cytokine IL- $1 \beta$, with caspase- 1 activity necessary for the proteolytic cleaving of pro-IL-1 $\beta$ (Gross et al., 2011). While NLRP inflammasomes are activated by the recognition of PAMPs or DAMPs (Bernier, 2012), the identification of host-derived DAMPs has become a major project, necessary for uncovering the pathway from insult to pathology.

The NLRP3 inflammasome and its downstream pathway has been recognized as a central mediator of systemic inflammation and a key mechanistic link between psychological stress and the emergence of depression and other psychiatric illnesses (Iwata et al., 2013). Much evidence has accumulated that ATP, found at higher extracellular concentrations following insult, potently induces NLRP-mediated IL-1 $\beta$ processing (Burnstock, 2008) and that its metabolite, adenosine, is also heavily involved in the modulation of this signaling pathway. ATP and other nucleotides, such as UTP are released from induced cells and provide "find-me" and "eatme" signals contributing to different phases of neuroinflammation by activating purinoceptors (Di Virgilio et al., 2009). Purinergic involvement in neuroinflammatory processes include the mediation of early events such as chemotaxis, microglia activation and the secretion of pro-inflammatory cytokines, phagocytosis, reactive astrogliosis and repair mechanisms such as neurogenesis.

Here we review the current understanding of the role of purinergic signaling in mediating the three phases of inflammation, the effect of the neuroinflammatory response on neuronal survival and functionality and the etiology and progression of CNS disease. Because the role of purinergic mechanisms in neurodegenerative diseases, such as AD, PD, SM, ALS and neuropathic pain is widely covered by other articles in this special issue; see (Burnstock, 2015), we will emphasize selected aspects which highlight the purinergic regulation of astrocytic and microglial cellular neuroinflammatory responses and their peculiar role in psychiatric disorders. Further elucidation of the participation of purinergic receptors in neuroinflammation will lead to a better of understanding of its role in neuropathology and may also pave the way towards more targeted and innovative therapies to combat CNS disorders.

\subsection{The role of $P 2 X$ receptors in neuroinflammation}

P2X receptors are ligand-gated cation channels, rendered permeable to $\mathrm{Na}^{+}, \mathrm{K}^{+}$and $\mathrm{Ca}^{2+}$ upon the binding of ATP (Abbracchio et al., 2009). Seven P2X subunits are expressed in the brain (P2X1-7), with P2X1-5 combining to form functional receptors with a heterotrimeric or homotrimeric quaternary structure, P2X6 forming only as a part of heterotrimeric receptors and P2X7 forming only homotrimers (North, 2002). Each combination of subunits forms a functional channel with different affinities for ATP and different desensitization dynamics conferring a variety in physiological responses to ATP; while P2X1 and P2X3 receptors desensitize within hundreds of milliseconds, P2X2 and P2X4 receptors desensitize an order of magnitude slower, and P2X7 receptors show very little desensitization, even over minutes (North and Jarvis, 2013). Both levels of subunit expression and receptor composition vary according to cell type and brain region. ATPaffinity and receptor function are also modulated by phosphorylation state and a host of allosteric and non-allosteric modulators, including heavy metals and reactive oxygen species (Coddou et al., 
2011).

Much evidence exists for changes in P2X subtype expression in neuroinflammatory conditions in various in vitro and in vivo models. For instance, early studies reported that P2X1 was strongly and transiently upregulated following ischemic insult in the hippocampus (Cavaliere et al., 2003), while P2X2 and P2X4 are upregulated in the dentate gyrus following oxygen and glucose deprivation in an organotypic hippocampal slice culture. Another study revealed an upregulation of P2X1 and P2X2 at the site of neurodegeneration following axotomy (Viscomi et al., 2004). P2X4 is expressed at increased concentrations in response to tissue injury following spinal cord injury (Schwab et al., 2005), traumatic brain injury (Zhang et al., 2006) and in spinal cord microglia following peripheral nerve injury (Tsuda et al., 2003; Ulmann et al., 2008). After stab wound injury, P2X1 and P2X7 receptor immunoreactivity was observed on astrocytes that were previously absent (Franke et al., 2004). Cerebellar lesions produce up-regulation of P2X1 and P2X2 receptors in precerebellar nuclei (Florenzano et al., 2002). The majority of these studies, however, lack evidence for a causative relationship between $\mathrm{P} 2 \mathrm{X}$ receptor activation and neuroinflammation.

Of the seven P2X subtypes, by far the strongest body of evidence for involvement in mediating neuroinflammation exists for P2X7 (Lister et al., 2007). Gene-linking and epidemiological studies have implicated P2X7 in a host of CNS diseases (Hansen et al., 2008; Ursu et al., 2014). In vivo studies, meanwhile, have been used to demonstrate the involvement of the P2X7 receptor in activating the inflammasome in a broad variety of rodent disease models, including cerebral ischemia (Kuan et al., 2015), epilepsy (Engel et al., 2012), Parkinson's disease (Marcellino et al., 2010), Alzheimer's disease (Diaz-Hernandez et al., 2012), depression and anxiety (Basso et al., 2009) and multiple sclerosis (Sharp et al., 2008). Systemic administration of bacterial lipopolysaccharide (LPS) markedly increases the expression of P2X7 receptors in the CNS (Choi et al., 2007), offering a mechanism for changes in CNS function in response to systemic infection.

A couple of features of the P2X7 receptor make it an optimal mediator of cellular responses to pathology. Firstly, the low-affinity of the receptor for ATP and its slow desensitization dynamics mean that it is unresponsive to micromolar fluctuations in extracellular ATP concentrations. This allows ATP signaling to function in different ways at different concentrations, with phasic micromolar ATP signaling operating via other $\mathrm{P} 2 \mathrm{X}$ receptors to modulate a number of physiological pathways, e.g. functioning as a neuromodulator at glutamatergic synapses (Gu and MacDermott, 1997), while millimolar concentrations, released into the extracellular milieu in response to injury, can act, via P2X7, as a DAMP, initiating neuroinflammatory cascades (Fiebich et al., 2014). Secondly, the pore-forming functionality of the P2X7 receptor facilitates the release of larger hydrophilic molecules, up to 900 Da (Surprenant et al., 1996), a process which may be important for initiating neuroinflammation. Indeed, the formation of the P2X7 receptor pore seems to be necessary for the role of the molecule in activating the inflammasome (Monif et al., 2009).

The principle function of the inflammasome is the cleavage, by the protease, caspase- 1 , of precursor interleukin molecules into the forms, IL-1 $\beta$ and IL-18 and the subsequent release of these proinflammatory cytokines into the extracellular space (Watanabe et al., 2007). This process involves three steps: firstly, synthesis of precursor molecules, e.g. pro-IL-1 $\beta$, secondly, the cleavage of the precursors into the active form, and thirdly, the release of the active form into the extracellular milieu. Synthesis of precursors is upregulated via the activation of toll-like receptors (TLRs) (He et al., 2013). Subsequently, NLRP1 or NLRP3 inflammasomes activated by PAMPs or DAMPs, induce the protease, caspase- 1 , which then cleaves pro-IL-1 $\beta$ into the active form (alongside IL-18). Thirdly, release of the active pro-inflammatory cytokines requires loading of the inflammasome complex into the secretory lysosome, or the formation of membrane blebs (Di Virgilio et al., 2009; Ferrari et al., 2006). ATP functions as a DAMP, via P2X7, activating the inflammasome and caspase-1 (Deplano et al., 2013) and is also involved in cytokine release, with modulation of cell membrane $\mathrm{K}^{+}$permeability being a key step in both processes. In this way, TLRs load the gun, while P2X7 receptors pull the trigger (Fig. 1).

$\mathrm{P} 2 \mathrm{X} 7$ receptor activation of the inflammasome in response to high extracellular concentrations of ATP seems to rely primarily on $\mathrm{K}^{+}$efflux through the cell membrane (Bernier, 2012; Lister et al., 2007). P2X7 receptor activation leads to an increase in permeability to $\mathrm{K}^{+}$, either directly through the P2X7 receptor pore, or through the opening of pannexin-1 hemichannels (Panx1). Reduced intracellular $\mathrm{K}^{+}$concentration is the primary trigger of caspase-1 activation (Munoz-Planillo et al., 2013). While some reports indicate that Panx1 channel opening is an obligatory part of both NLRP1 and NLRP3 inflammasome activation (de Rivero Vaccari et al., 2008; Pelegrin and Surprenant, 2006; Silverman et al., 2009), other groups have reported P2X7 receptor-induced IL-1 $\beta$ release, independent of Panx1 (Pelegrin et al., 2008; Qu et al., 2011). A further study postulated that Panx1 is responsible for the release of ATP from dying cells, upstream of P2X7 activation in the signaling cascade (Dahl and Keane, 2012). Alternatively, Panx1 hemichannels may open in response to an increase in extracellular $\mathrm{K}^{+}$as a result of P2X7 pore opening (Bernier, 2012), acting to amplify $\mathrm{K}^{+}$efflux.

P2X7 receptors are found in highest concentrations on microglia, but are also expressed on astrocytes, oligodendrocytes and neurons, particularly at presynaptic terminals (Weisman et al., 2012). P2X7 receptor expression on different cell types, upregulated in response to CNS insult, combines to mediate a neuroinflammatory response. ATP-activated microglia are key regulators of the neuroinflammatory response, releasing IL- $1 \beta$ in response to insult (Ferrari et al., 1997; Silverman et al., 2009), adopting an activated morphology, proliferating and migrating to the site of insult, to form an inflammatory focus. It has been demonstrated that P2X7 receptor overexpression is both necessary and sufficient to drive these processes (Monif et al., 2009). Other studies (de Rivero Vaccari et al., 2012), however, revealed the importance of IL-1 $\beta$ release from neurons, while Silverman et al. (Silverman et al., 2009) report that in neurons, high extracellular $\mathrm{K}^{+}$can activate the inflammasome via Panx1-dependent efflux. These latter data indicate that neurons may be the first site of IL- $1 \beta$ release following an insult (Fig. 1).

Further, P2X7 receptor stimulation of enteric neurons elicits a direct release of ATP onto glia through Panx1 (Gulbransen et al., 2012). By way of this paracrine signaling, the P2X7 receptor can function as a gatekeeper between glia and neurons to regulate inflammatory cascades (Browne, 2013). Astrocytic P2X7 receptor expression has also been implicated in contributing to the inflammatory response, with the activation of astroglial P2X7 receptors leading to a neurotoxic phenotype in a model of ALS (Gandelman et al., 2010), while following trauma, astroglial P2X7 receptor activation leads to upregulation of the chemokine, monocyte chemoattractant protein-1 (MCP-1) and, subsequently an increased invasion of systemic immune cells into the site of insult (Panenka et al., 2001).

As previously described, there is plenty of evidence for changes in $\mathrm{P} 2 \mathrm{X}$ receptor expression during neuroinflammation, but other than P2X7, there is little evidence that these receptors mediate the process. Evidence is accumulating, however, that P2X4 receptors may also play a role. P2X4 knockouts show less microglial activation and the loss of the prostaglandin E2-mediated inflammatory pathway (Ulmann et al., 2010). P2X4 receptors, similarly to P2X7, 


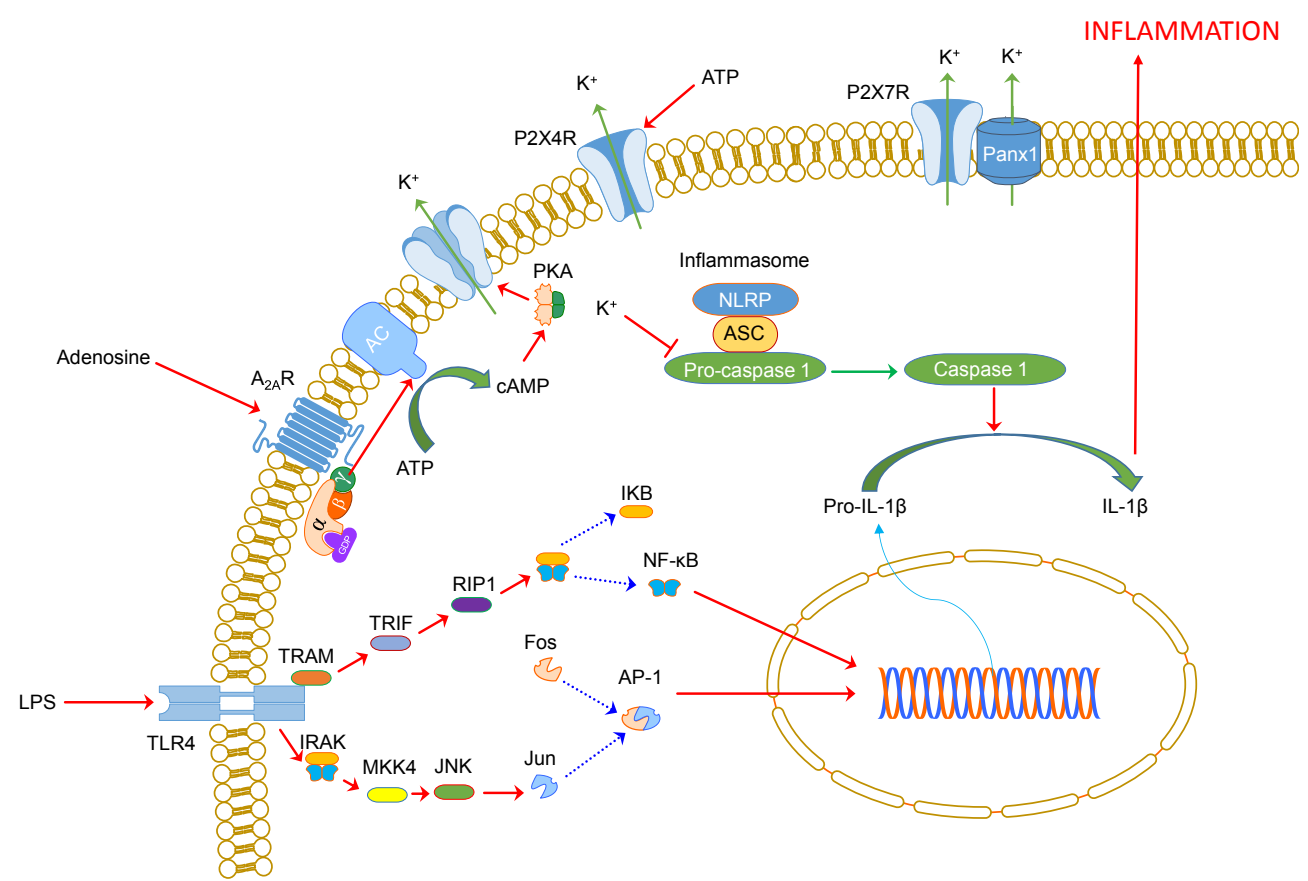

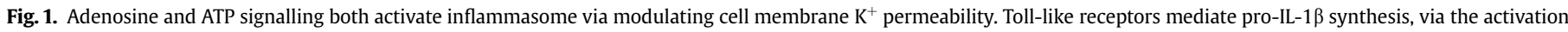

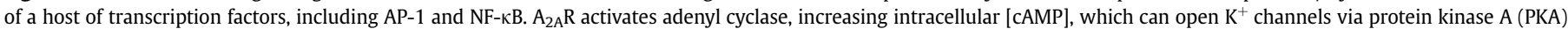

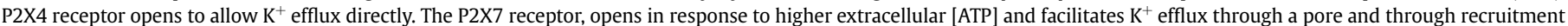
of Panx1.

form a large conductance pore on the cell membrane, facilitating ion efflux and subsequently inflammasome activation (Fiebich et al., 2014). Interestingly, this process appears to be Panx1independent (Bernier, 2012). A recent study showed that P2X4 knockout mice displayed impaired inflammasome activation resulting in a decrease in extracellular IL-1 $\beta$ and reduced infiltration of neutrophils and monocyte-derived M1 macrophages following spinal cord injury (de Rivero Vaccari et al., 2012). Further, Compan et al. (2012) report that receptors made up of P2X2 and P2X5 subunits, which are expressed in specific neuronal populations, also show an ability to form a P2X7 receptor-like dilated pore, suggesting that these receptors may also function as gatekeepers of the inflammasome. Because P2X receptors other than P2X7 have lower affinity to extracellular ATP, sequential inflammasome activation by distinct $\mathrm{P} 2 \mathrm{X}$ receptors might represent responses to insults of different intensity. While the P2X4 receptor may act as an initial trigger, the P2X7 receptor, in concert with Panx1, may amplify the signal (Fig. 2).

\subsection{The role of P2Y receptors in neuroinflammation}

P2Y receptors are metabotropic receptors activated by adenine and uridine nucleotides and belong to the superfamily of $G$ protein coupled receptors. So far eight subtypes of P2Y subfamily have been

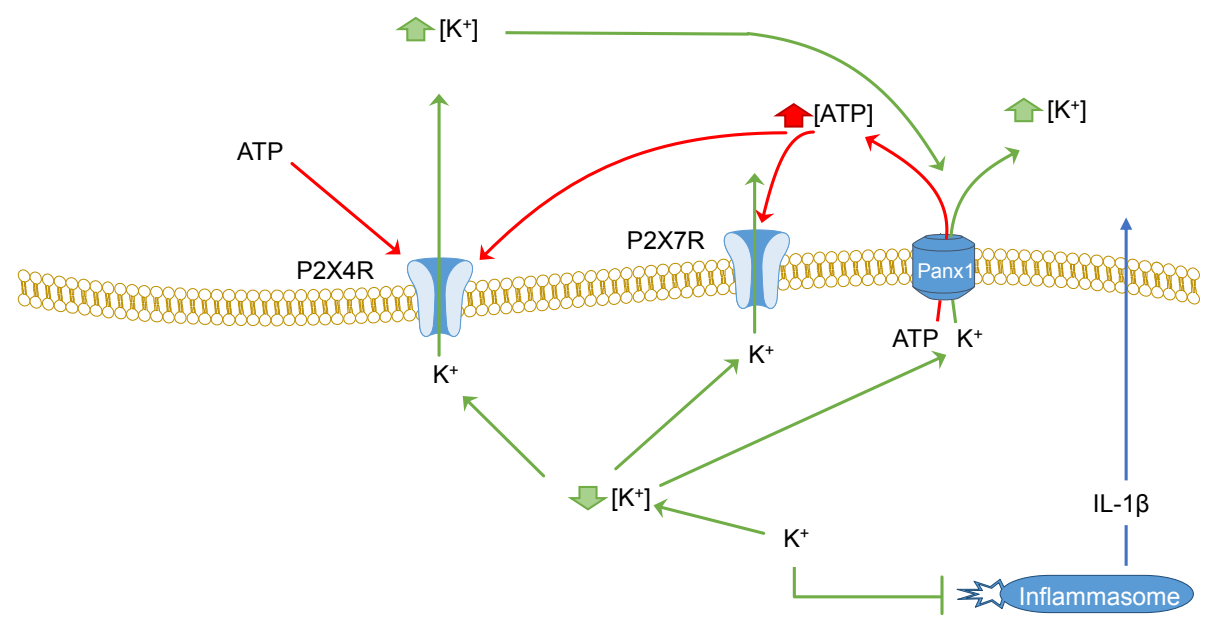

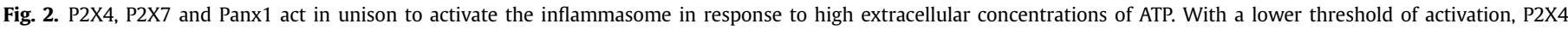

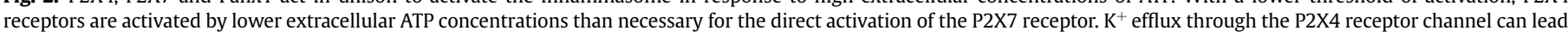

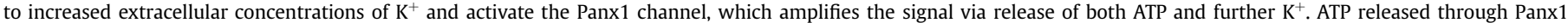

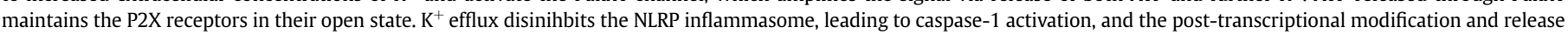
of the pro-inflammatory cytokine IL- $1 \beta$. 
identified $\left(\mathrm{P}_{2} \mathrm{Y}_{1}, \mathrm{P}_{2} \mathrm{Y}_{2}, \mathrm{P}_{2} \mathrm{Y}_{4}, \mathrm{P}_{2} \mathrm{Y}_{6}, \mathrm{P}_{2} \mathrm{Y}_{11}, \mathrm{P}_{2} \mathrm{Y}_{12}, \mathrm{P}_{2} \mathrm{Y}_{13}\right.$ and $\left.\mathrm{P} 2 \mathrm{Y}_{14}\right)$, which are divided into two subgroups i.e. those coupled by $\mathrm{Gq}$ $\left(\mathrm{P}_{2} \mathrm{Y}_{1}, \mathrm{P}_{2} \mathrm{Y}_{2}, \mathrm{P}_{2} \mathrm{Y}_{4}, \mathrm{P}_{2} \mathrm{Y}_{6}, \mathrm{P}_{2} \mathrm{Y}_{11}\right)$ and those coupled by Gi (P2Y 12 , $\mathrm{P}_{2} \mathrm{Y}_{13}$ and $\mathrm{P}_{2} \mathrm{Y}_{14}$ ) (Pelegrin et al., 2008; Qu et al., 2011). Like P2X, $\mathrm{P} 2 \mathrm{Y}$ receptors also differ in their agonist binding profiles, with one group specific to adenine nucleotides ( $\left.\mathrm{P}_{2} \mathrm{Y}_{1}, \mathrm{P}_{2} \mathrm{Y}_{12}, \mathrm{P}_{2} \mathrm{Y}_{13}\right)$, another group ( $\mathrm{P}_{2} \mathrm{Y}_{2}$ and rodent $\mathrm{P}_{2} \mathrm{Y}_{4}$ ) activated by both adenine and uridine nucleotides, a third group specific to uridine nucleotides (human $\mathrm{P}_{2} \mathrm{Y}_{4}$ and $\mathrm{P}_{2} \mathrm{Y}_{6}$ ) and $\mathrm{P}_{2} \mathrm{Y}_{14}$ activated by UDP-glucose (Jokela et al., 2014). All known subtypes of $\mathrm{P} 2 \mathrm{Y}$ receptors are expressed in the CNS with variable distribution among different cell types (i.e. neurons, astrocytes, microglia, oligodendrocytes) (Burnstock and Knight, 2004). These receptors are activated during pathological conditions and participate in neuroinflammation in many different ways. The majority of data are derived from cell culture models of neuroinflammation and are yet to be replicated in in vivo assays using specific probes to identify receptor subtypes (e.g. gene deficient mice, shRNA). Nevertheless, we highlight here the most important functions attributed to $\mathrm{P} 2 \mathrm{Y}$ receptors in the regulation of neuroinflammation.

$\mathrm{P}_{2} \mathrm{Y}_{1}$ receptors are expressed by neurons, astrocytes, oligodendrocytes and microglia and their primary postulated function is neuromodulation. In addition a recent study found that $\mathrm{P}_{2} \mathrm{Y}_{1}$ receptors expressed on astrocytes can be activated under conditions of oxidative stress, stimulating the release of IL-6. In this way, P2Y acts as a gatekeeper of astrocyte-mediated neuroprotection (Fujita et al., 2009).

Uridine nucleotide-sensitive $\mathrm{P}_{2} \mathrm{Y}_{2}$ receptors are expressed by neurons, astrocytes and microglia and a growing number of studies implicate a role in neuroinflammation. Uniquely amongst the P2Y family, these receptors possess a consensus integrin-binding motif which interacts with avB3/5 intergin, regulating actin polymerization and cytoskeletal rearrangements through the Rac/Rho pathways (Weisman et al., 2012). ${\mathrm{P} 2 Y_{2}}_{2}$ receptors are upregulated in animal models of inflammation and, interestingly, P2X7 receptor activation on astrocytes and microglia act as a signal to upregulate $\mathrm{P}_{2} \mathrm{Y}_{2}$ receptors through the release of the proinflammatory cytokine IL-1 $\beta$. The activation of $\mathrm{P}_{2} \mathrm{Y}_{2}$ confers neuroprotection, particularly in $\mathrm{AD}$, through several pathways: the promotion of neurite outgrowth, increases in cell motility, the processing of nonamyloidogenic APP and enhancement of phagocytosis and degradation of the $A \beta$ peptide (Erb et al., 2015; Kim et al., 2012; Weisman et al., 2012). Using a TgCRND8 mouse model of AD, Ajit, et al. (2014) demonstrated both that $\mathrm{P}_{2} \mathrm{Y}_{2}$ expression is enhanced in concert with the AD phenotype, and that genetic deletion of $\mathrm{P}_{2} \mathrm{Y}_{2}$ enhances early AD pathology. In addition $\mathrm{P}_{2} \mathrm{Y}_{2}$ receptors expressed on satellite glia participate in the sensitization leading to trigeminal pain (Magni et al., 2015).

In comparison with $\mathrm{P}_{2} \mathrm{Y}_{2}$ receptors, the data on the involvement of $\mathrm{P}_{2} \mathrm{Y}_{4}$ receptors in neuroinflammation is relatively sparse. Although the expression of $\mathrm{P}_{2} \mathrm{Y}_{4}$ receptors in microglia is well documented, e.g. (Bianco et al., 2005; Fumagalli et al., 2003), the lack of specific tools to probe the receptor mean that a full understanding of its role remains elusive. In addition to $\mathrm{P}_{2} \mathrm{Y}_{2}$ and $\mathrm{P}_{2} \mathrm{Y}_{4}$, $\mathrm{P}_{2} \mathrm{Y}_{6}$ receptors are also activated by uridine nucleotides, particularly UDP. These receptors regulate the phagocytic activity of microglia in vivo (Inoue, 2007). This process may be important under conditions of neuronal damage. UDP, leaking out from damaged hippocampal cells facilitates the uptake of cellular debris by microglia in a $\mathrm{P}_{2} \mathrm{Y}_{6}$-dependent manner (Koizumi et al., 2007).

Because there is no rodent orthologue of the $\mathrm{P}_{2} \mathrm{Y}_{11}$ receptor, our knowledge regarding its role in neuroinflammation is limited. While P2Y ${ }_{11}$ mRNA can be found in the nervous system (Burnstock and Knight, 2004), and these receptors are expressed on human immunocytes and regulate neurotrophil apoptosis (Communi et al.,
1999; Vaughan et al., 2007), a potential immunomodulatory role in the CNS may also be hypothesized.

$\mathrm{P}_{2} \mathrm{Y}_{12}$ receptors are $\mathrm{G}_{\mathrm{i}}$-coupled receptors and well-known as the target site of widely used antithrombotic drugs such as clopidogrel or ticagrelor, and are therefore of considerable interest to cardiovascular medicine. Activation of $\mathrm{P}_{2} \mathrm{Y}_{12}$ receptors by ADP leads to rapid platelet aggregation. The inhibition of this effect is utilized in the clinic to prevent myocardial infarction and stroke. P2Y 12 receptors, expressed on platelets, regulate various forms of inflammation and could either improve or worsen the scenario (Liverani et al., 2014a). In the CNS, $\mathrm{P}_{2} \mathrm{Y}_{12}$ receptors are expressed on astrocytes, oligodendrocytes and the resting, ramified microglia executing surveillant functions (Amadio et al., 2014; Franke et al., 2004).

The very first report indicating that $\mathrm{P}_{2} \mathrm{Y}_{12}$ receptors regulate the reactivity of microglia showed that $\mathrm{P}_{2} \mathrm{Y}_{12}$ receptors are instrumental for microglial chemotaxis in response to local brain injury. The expression of $\mathrm{P}_{2} \mathrm{Y}_{12}$ decreases during the morphological change from the resting ramified to activated amoeboid state associated with microglial activation (Haynes et al., 2006). Recent investigation using in vivo two photon microscopy technologies confirmed a key role for $\mathrm{P}_{2} \mathrm{Y}_{12}$ receptors in the regulation of microglial dynamics in response to other alarm signals. For example, during epileptic seizures, excess glutamate is released, which promotes microglial process extension towards the site of damage. This process involves the activation of neuronal NMDA receptors, calcium influx, subsequent ATP release, and the activation of $\mathrm{P}_{2} \mathrm{Y}_{12}$ receptors (Eyo et al., 2014).

A similar phenomenon, described recently and termed microglial process convergence (MPC) involves the convergence of microglial processes on neuronal dendrites in response to a reduction of extracellular $\mathrm{Ca}^{2+}$ (Eyo et al., 2015). The induction of microglial migration, morphological transformation and process extension towards various pathological signals by $\mathrm{P}_{2} \mathrm{Y}_{12}$ receptors probably represents a protective mechanism which could be beneficial during early stages of injury. Accordingly, the protective role of microglial $\mathrm{P}_{2} \mathrm{Y}_{12}$ receptors against brain ischemia (Webster et al., 2013) or LPS induced sepsis (Liverani et al., 2014b) has been demonstrated. In the case of a more pronounced stroke model, however, the pro-inflammatory action of $\mathrm{P}_{2} \mathrm{Y}_{12}$ receptor activation prevails and pharmacological blockade of the receptor in this case is protective (Gelosa et al., 2014). In addition to $\mathrm{P}_{2} \mathrm{Y}_{12}$ receptor expression on microglia, oligodendrocytic expression may be an important marker of demyelinating lesions in the neuroinflammatory disease, ALS (Amadio et al., 2014).

$\mathrm{P}_{2} \mathrm{Y}_{13}$ receptors expressed by cerebellar astrocytes and neurons confer neuroprotection through the activation of the GSK3 ERK1/2 pathway (Perez-Sen et al., 2015). Finally P2Y 14 receptors are also expressed by microglia, however these receptors are exclusively sensitive to UDP-glucose and other conjugates of UDP but not adenine or uracil nucleotides (Bianco et al., 2005). Again, the participation of $\mathrm{P}_{2} \mathrm{Y}_{14}$ receptors in neuroinflammation may be identified by future studies, as their role in the regulation of cell stress and repair in the periphery implicate a similar role in the nervous system (Jacobson et al., 2015).

\subsection{The role of adenosine in neuroinflammation}

Extracellular concentrations of adenosine are regulated by direct release from cells (Melani et al., 2012), extracellular metabolism of released ATP (Zimmermann, 2000) and reuptake into cells followed by intracellular metabolism (Bender and Hertz, 1986). Adenosine is principally metabolized in the CNS by adenosine kinase, an enzyme expressed in highest concentrations in astrocytes (Studer et al., 2006). Extracellular concentrations of 
adenosine in the CNS are regulated by three nucleoside transporters expressed on astrocytes (Peng et al., 2005), with adenosine release, uptake and metabolism forming an 'adenosine-cycle', described in detail by Boison (2008). Following metabolic stress and cell damage, for example, under conditions of high neuronal activity or brain injury, the extracellular concentration of adenosine is dramatically elevated where it acts, in concert with ATP, as an alarm molecule, promoting or inhibiting neuroinflammation, depending on a host of complex factors, which are only beginning to be understood.

Cellular responses to extracellular adenosine are co-ordinated by four different metabotropic P1 receptor subtypes: $A_{1} A_{2 A}, A_{2 B}$ and $A_{3}$. Of these, the $A_{1}$ receptor and $A_{3}$ receptor inhibit the production of cAMP, via $G_{i}$ protein signaling, while the $A_{2 A}$ receptor and $A_{2 B}$ receptor increase intracellular concentrations of cAMP via $\mathrm{G}_{\mathrm{s}}$ (Fredholm et al., 2007). As such, these receptors in general act in opposition to each other and the cellular response depends on the concentration of receptors expressed, their affinity for adenosine, activation dynamics, extracellular adenosine concentrations and other complex factors (Chen et al., 2014). In addition to classical cAMP-mediated pathways, evidence is accumulating for P1 receptors operating through alternative signaling systems. Of particular note, evidence for protein kinase C (PKC), phosphoinositide 3 kinase (PI3K) kinase and mitogen activated protein kinase (MAPK) involvement in P1-mediated signaling cascades have been reported (Schulte and Fredholm, 2003). Further, the direct activation of $\mathrm{K}^{+}$channels and inhibition of $\mathrm{Ca}^{2+}$ channels has been reported following $A_{1}$ receptor activation (Hasko and Pacher, 2008).

While P1 receptor expression in the CNS is dominated by $A_{1}$ and $A_{2 A}$, the extent of $A_{2 B}$ and $A_{3}$ receptor expression is contentious, but as these receptors mediate inflammatory responses on immune effector cells in the periphery (Latini and Pedata, 2001), they may also play an important role in mediating neuroinflammatory processes, even at low concentrations. On microglia, van der Putten et al. reported $A_{1}, A_{2 A}$ and $A_{3}$ receptor expression, but not $A_{2 B}$ (van der Putten et al., 2009), whereas a more recent report revealed the presence of the $A_{2 B}$ receptor on microglia, and an important role for this receptor in augmenting the production of the cytokine, IL-10 (Koscso et al., 2012). The difficulty in ascertaining P1 subtype expression on specific cell types lies in the possible introduction of experimental artifacts from cell culture methods, detection limits associated with anatomical methods and specificity issues relating to physiological approaches using pharmacological tools. Nevertheless, the available data collectively suggest that all four receptor subtypes are expressed on astrocytes, oligodendrocytes and microglia (Boison, 2012). Evidence also indicates that P1 receptor expression can be modulated by neuroinflammatory conditions themselves (Orr et al., 2009).

$\mathrm{P} 1$ receptors can play a role in inflammasome activation through the classical cAMP-pathway. Chiu et al. reported that, following $A_{2 A}$ receptor activation, $\mathrm{K}^{+}$efflux is increased via an intracellular elevation of cAMP and, subsequent protein kinase A (PKA) activation (Chiu et al., 2014). As described previously, $\mathrm{K}^{+}$efflux stimulates the activation of caspase- 1 via increases in extracellular $\mathrm{K}^{+}$, decreased intracellular $\mathrm{K}^{+}$concentrations, or both (Bernier, 2012). The relative concentration of $\mathrm{K}^{+}$in the intra- and extracellular compartments appears to be a key point where P2X and P1 signaling converges to modulate inflammasome activation (Fig. 1). Moreover, an increase in extracellular adenosine concentration stimulates both caspase- 1 activity and IL- $1 \beta$ production (Chiu et al., 2014). As $A_{1}$ and $A_{3}$ receptors act in opposition to $A_{2 A}$ receptors, it is likely that the cellular response to high levels of extracellular adenosine is, to some extent dependent on the ratio of receptors expressed, however, alternative, non-cAMP-dependent pathways are also likely to be of importance.
Rebola et al. reported that the $A_{2 A}$ receptor is the primary receptor involved in mediating neuroinflammation in response to increases in extracellular concentrations of adenosine, not only via activation of the inflammasome and subsequent increases in IL- $1 \beta$ production, but also by the recruitment and activation of microglia and alterations in astrocyte function (Rebola et al., 2011). Microglial process retraction and activation is of critical importance to the neuroinflammatory response, and P1 receptors are key modulators of this process. During chronic neuroinflammation, process retraction is mediated by the upregulation of the $A_{2 A}$ receptor (Orr et al., 2009). As an example, a recent study showed that microglial process retraction in a mouse model of Parkinson's disease is $A_{2 A}$ receptor-dependent (Gyoneva et al., 2014), while Ohsawa et al. postulate an important role for the $A_{3}$ receptor in mediating this process (Ohsawa et al., 2012). Further, $A_{2 A} R$ activation on microglia induces COX-2 expression (Fiebich et al., 1996), an important marker and mediator of inflammation. The effect of microglial $A_{1}$ receptor activation can be either pro- or anti-inflammatory, depending on other factors in the environment (Hasko et al., 2005); however, both neuroinflammation and microglial activity is enhanced in an $A_{1 A}$ knockout mouse strain under pathological conditions, suggesting that the primary role of $A_{1 A}$ receptor signaling is anti-inflammatory (Luongo et al., 2014).

Astrocytes also play an important role in mediating neuroinflammation, not least, by modulating extracellular concentrations of ATP and adenosine, as previously discussed. P1 receptors expressed on astrocytes are vital components in mediating this process. In addition, pharmacological $A_{2 A}$ receptor blockade inhibited astrogliosis in primary astroglial cultures (Brambilla et al., 2003). Because astrocytes are responsible for the maintenance of adenosine concentrations in the extracellular environment, through adenosine kinase, astrogliosis can lead to a decrease in extracellular adenosine. Fedele et al. (2005) demonstrated that astrogliosis contributes to ictogenesis via an ADK-dependent increased removal of adenosine from the extracellular space.

Whether increased extracellular adenosine concentrations have a pro- or anti-inflammatory effect is unclear, and appears to be dependent on other variables, such as relative expression of different P1 receptors. Hindley et al. report that direct cortical injections of an adenosine analog 5'-(N-cyclopropyl)-carboxamidoadenosine, triggered reactive gliosis, which could be reversed with $A_{2}$ receptor blockade, suggesting the primary effect of high extracellular adenosine concentrations in the CNS is proinflammatory and mediated by $\mathrm{A}_{2 \mathrm{~A}}$ receptor activation (Hindley et al., 1994). Another study, however, report that specific $A_{3}$ agonists provide neuroprotection against ischemia (Choi et al., 2011). The effect of glial activation on neuroinflammation and neuronal cell fate is likely to depend on specific conditions. $A_{2 A}$ receptor agonists reduce long-term neurologic injury after blunt spinal trauma (Reece et al., 2004), while a similar treatment improves recovery following experimental stroke (Pedata et al., 2014), in contrast to reports of the proinflammatory action of this receptor.

In summary, the role of adenosine in mediating neuroinflammation is multi-factorial, involving activation of the inflammasome and the recruitment and activation of astrocytes and microglia. The $A_{1}$ receptor and $A_{3}$ receptor act in opposition to the $A_{2 A}$ and $A_{2 B}$ receptor in cAMP-mediated pathways, which are sufficient to explain much of the cellular response. The net effect of increased extracellular adenosine however is dependent on pathology, adenosine concentrations, receptor expression and cross-talk with pathways mediated by ATP and other signaling molecules. Conflicting reports of whether adenosine is pro- or anti-inflammatory underscore the complexity of this molecule's role in mediating neuroinflammatory cascades (Liang et al., 2014). 


\subsection{Purinergic regulation of neuroinflammation in CNS disorders}

The role of purinergic receptors has been implicated in the majority of CNS diseases, characterized or accompanied by neuroinflammation. Because purinergic signaling in various neurodegenerative diseases are discussed in detail elsewhere in this issue (Burnstock, 2015), we focus here on non-organic psychiatric disorders, which are also coupled to inflammation and the repair process. Neuroimmunological alterations appear in classical psychiatric disorders, such as major depressive disorder (MDD), bipolar disorder (BD), obsessive compulsive disorder (OCD) and schizophrenia. Medical conditions associated with chronic inflammation, such as diabetes, obesity, or autoimmune diseases share comorbidity or increase the risk of psychiatric disorders, such as MDD. In contrast to neurodegenerative diseases, however, these disorders are characterized by chronic, low grade or intermittent inflammation, rather than a robust acute inflammation in the brain parenchyma, which is present e.g. after stroke or seizures.

As a reflection of inflammation in the peripheral blood, many human studies have revealed an altered innate immune status and cytokine profile in patients suffering from major depression and schizophrenia. For instance, a recent meta-analysis collecting data from 29 individual studies reported that serum IL-2 receptor, IL-6 and tumor necrosis factor- $\alpha$ (TNF- $\alpha$ ) levels are elevated in MDD patients (Liu et al., 2012; Najjar et al., 2013). Among these, IL-6 and TNF- $\alpha$, correlate with exacerbation and normalization of depressive episodes and the risk of suicide attempts, and are therefore proposed to not only be trait but also state markers of the disorders (Janelidze et al., 2011). This molecular profile is consistent with a Th1-proinflammatory immunophenotype. In contrast to acute neuroinflammatory conditions in MDD, however, astroglia and microglia do not proliferate (Najjar et al., 2013), consistent with a continuous, low grade inflammation. As for BPD, peripheral IL-2, IL4 and IL-6 are found to be increased in manic episodes (Brietzke et al., 2011) whereas another meta-analysis revealed significant elevation of soluble interleukin (IL)-2 receptor (sIL-2R), TNF- $\alpha$, soluble tumor necrosis factor receptor type 1 (sTNFR1) and soluble interleukin (IL)-6 receptor (sIL-6R) (Munkholm et al., 2013). In the case of schizophrenia, TNF- $\alpha$, IFN- $\gamma$, IL-12 and IL- 2 are consistently elevated in chronic schizophrenic patients, while IL-1 $\beta$, IL-6 and TGF- $\beta$ correlate positively with disease activity (Miller et al., 2011).

Schizophrenia is also regarded as a neurodevelopmental disorder, and fetal neuroinflammation, which could be the consequence of maternal infection (Meyer, 2013), is implicated in its etiology. Fetal neuroinflammation is characterized by enhanced levels of proinflammatory cytokines in the brain and enhanced microglial activation, which changes neurodevelopmental trajectories and thereby predisposes the developing brain to long-term pathology, which is later manifested, during adolescence. During the postnatal period, further postnatal stressors can induce or maintain neuroinflammation during development leading to abnormal brain maturation and behavioral changes in the prodromal period, which eventually develop into an overt psychosis. Because purinergic mechanisms, in particular $\mathrm{P} 2 \mathrm{X} 7$ receptors, regulate many aspects of neuroinflammation, it is unsurprising that emerging evidence indicates their activation and participation in animal models of psychiatric disorders.

In rodent studies mimicking depressive-like behaviors, both genetic deletion and pharmacological inhibition of $\mathrm{P} 2 \mathrm{X} 7$ receptors lead to an antidepressant phenotype, which is manifested in the widely used forced swim (FST) and tail suspension tests (TST) (Basso et al., 2009; Boucher et al., 2011; Csolle et al., 2013a,b; Pereira et al., 2013; Wilkinson et al., 2014), but can also be measured using more complex paradigms such as learned helplessness (Iwata et al., 2013). Acute stress induced depressive-like behaviors, following LPS challenge are also alleviated by P2X7 receptor antagonism, (Csolle et al., 2013b; Ma et al., 2014). When footshocks were used as a stressor, however, no change in behavior was found in the presence of a P2X7 antagonist (Catanzaro et al., 2014). Conflicting results were obtained using chronic stress models: chronic restraint leads to a downregulation of P2X7 mRNA throughout the hippocampus (Kongsui et al., 2014), whereas another study found a markedly upregulated Cx43 and Panx1 opening in the hippocampus under similar conditions, mediated by NMDA/P2X7 receptor signaling (Orellana et al., 2015). Interestingly, a very recent study of the same group revealed that a similar upregulation of the Cx43 and Panx1 pathway can be detected in offspring in response to maternal LPS treatment (Avendano et al., 2015).

Interestingly, ATP alone also elicits a rapid antidepressant-like effect if added directly to the CNS in the chronic social defeat model of depression, an effect probably mediated by P2X2 receptors in the medial prefrontal cortex (Cao et al., 2013). To study the manic pole of bipolar disorder, genetic deficiency and pharmacological blockade of $\mathrm{P} 2 \mathrm{X} 7$ receptors attenuated hyperactivity induced by amphetamine in all studies examined (Bhattacharya et al., 2013; Csolle et al., 2013a; Gubert et al., 2014; Lord et al., 2014). These findings indicate that the presence and endogenous activation of $\mathrm{P} 2 \mathrm{X} 7$ receptors contributes to behavioral changes induced by either negative or positive challenges, and the blockade of the receptor alleviates these fluctuations.

Several attempts have been made to correlate behavioral changes with neuroinflammatory parameters, in particular with IL$1 \beta$ levels in the CNS and periphery, given the well-established role of $\mathrm{P} 2 \mathrm{X} 7 \mathrm{~s}$ in the regulation of posttranslational processing of this cytokine. However, it appears that the scenario is more complex as only LPS-induced, but not the basal IL- $1 \beta$ levels are subject to regulation by $\mathrm{P} 2 \mathrm{X} 7$ receptors in the rodent brain (Csolle and Sperlagh, 2010; Mingam et al., 2008) and the mood stabilizing phenotype detected in the absence of P2X7 receptors was not transferred with bone marrow transplantation (Csolle et al., 2013b). The contribution of P2X7 receptors present on cells of hematopoietic origin such as peripheral immune cells to behavioral changes detected in naïve animals, therefore, seems minimal.

Rather, P2X7-regulated intrinsic neuronal mechanisms such as the modulation of glutamatergic neurotransmission (Csolle et al., 2013b) or nitric oxide signaling (Pereira et al., 2013) may represent the underlying mechanisms of the antidepressant phenotype. On the other hand, amphetamine induced induction of IL-1 $\beta$ and oxidative stress (Gubert et al., 2014) in the striatum were reversed by a P2X7 receptor antagonist coincidently with the alleviation of amphetamine induced behavior and amphetamine induced striatal dopamine release is attenuated by the P2X7 receptor deficient genotype (Csolle et al., 2013a). The lack of local IL-1 $\beta$ induction and subsequent modulation of dopamine release in the absence of P2X7 receptor could explain the alleviation of amphetamine induced hyperlocomotion. Interestingly, ATP-induced cell death in the hippocampus - a process probably mediated by $\mathrm{P} 2 \mathrm{X} 7$ receptors - was reversed by the mood stabilizer drugs lithium and valproate (Wilot et al., 2007), therefore the action of currently used drugs against bipolar disorder might also involve P2X7 receptors.

Although less data have been accumulated, a recent study suggests that P2X7 receptors also regulate social behavior, an important aspect of psychiatric disorders. While JNJ-42253432, a novel brain-penetrant P2X7 receptor antagonist, did not affect footshock induced decreases in social interactions, it elicited a robust increase in overall social activity (Lord et al., 2014). Therefore, P2X7 receptor modulation may represent an intriguing possibility for interfering with neuropsychiatric conditions characterized by social deficit (e.g. schizophrenia, autism). In 
addition, although the underlying receptor subtype has not been identified yet, a line of recent studies found that suramin, a broad spectrum purinergic antagonist, attenuates the whole variety of neurobiological and phenotypic alterations in different animals models of autism spectrum disorder, including the poly(I:C) model representing maternal immune activation (Naviaux et al., 2014, 2015, 2013).

Finally the neuroinflammatory response evoked by the recreational drug 3,4 -methylenedioxymethamphetamine (MDMA, ectasy) also appear to involve the activation of $\mathrm{P} 2 \mathrm{X} 7$ receptor: MDMA-induced BBB leakage, subsequent microglial activation and metalloproteinase induction were suppressed by in vivo treatment with specific P2X7 receptor antagonists (Rubio-Araiz et al., 2014).

Apart from the nucleotide-sensitive receptors detailed above, the role of adenosine receptors have also been examined in animal models of psychiatric disorders, although adenosine mediated control of neuroinflammatory mechanisms has not been envisaged in this respect. Adenosine has been reported to have an antidepressant-like effect in the forced swim paradigm, and this effect has been attributed to the activation of both $A_{1}$ and $A_{2 A}$ receptors (Kaster et al., 2004) and the subsequent involvement of $\mathrm{K}^{+}$ conductances (Kaster et al., 2007a) and the endogenous opioidergic system (Kaster et al., 2007b). Orally administered inosine also reproduces this effect (Muto et al., 2014). Interestingly $A_{2 A}$ receptor gene deficiency and $\mathrm{A}_{2 \mathrm{~A}}$ receptor antagonists, including caffeine, also have antidepressant-like effect in the FST and TST (El Yacoubi et al., 2003; Hodgson et al., 2009) as well as in the chronic unpredictable stress paradigm of depression (Pechlivanova et al., 2012).

The antidepressant effect of $\mathrm{A}_{2 \mathrm{~A}}$ antagonists are most likely mediated by $D 2$ receptors in the ventral striatum (El Yacoubi et al., 2003). More recently, it was found that the rapid antidepressantlike effect of sleep deprivation is mediated by astrocyte-derived adenosine as it is absent in $A_{1}$ receptor knockout and astrocytedeficient dnSNARE mice and can be mimicked by CCPA, an $A_{1}$-selective agonist (Hines et al., 2013). Further, astrocyte-specific deletion of $\mathrm{A}_{2 \mathrm{~A}}$ receptors mimics certain features of the schizophrenia endophenotype, such as decreased working memory and enhanced psychomotor response to the NMDA antagonist MK-801 (Matos et al., 2015). These data point to the role glia-neuron cross talk in the action of endogenous adenosine on behavior. A potentially fruitful area of further investigation could be the identification of a link between the impact of adenosine receptors on neuroinflammatory mechanisms and its role in neuropsychiatric disorders.

The assumption underlying most research involving the role of purinergic signaling in neuroinflammation is that inflammatory responses exacerbate injury. However, the complex pathways leading to inflammasome activation are highly conserved, suggesting a strong adaptive value. It is likely, therefore, that reducing neuroinflammation associated with pathology is not necessarily always of value. Roth et al. (2014) investigated the role of purinergic signaling in neuroinflammatory responses following TBI and found that the P2X7-mediated inflammatory response contributes to better outcomes, with activated microglia protecting the parenchyma and myelomonocytic cells invading the damaged meninges. Both purinergic mechanisms and reactive oxygen species are key players in the response to injury. In this study, these pathways could be manipulated by delivering pharmacological agents transcranially.

\section{Conclusion}

Purines are ubiquitous extracellular mediators, which are released to the extracellular space under conditions of inflammation. Among various subtypes of purinergic receptors, both P1 and
P2 receptors participate in the regulation of the inflammatory response of the CNS in a complex way, i.e. in the activation of the inflammasome, the synthesis and posttranslational processing of IL-1 $\beta$ and other pro- and anti-inflammatory cytokines, the recruitment and activation of microglia and in reactive astrogliosis. Under pathological conditions purinergic receptors are up-/or downregulated, and therefore the contribution of purinergic regulation dynamically changes during acute and chronic phases of neuroinflammation.

\section{Conflicts of interest}

None.

\section{Acknowledgments}

This study was supported by research grants from the Hungarian Research and Development Fund (Grant NN107234 to B.S.), the European Research Council (Grant 294313-SERRACO to B.S.), and the Hungarian Brain Research Program [KTIA_13_NAP-A-III/1 to B.S.]. Ed Beamer is the recipient of the postdoctoral fellowship of the Hungarian Academy of Sciences (1255/215/2015/KIF).

\section{References}

Abbracchio, M.P., Burnstock, G., Verkhratsky, A., Zimmermann, H., 2009. Purinergic signalling in the nervous system: an overview. Trends Neurosci. 32, 19-29.

Ajit, D., Woods, L.T., Camden, J.M., Thebeau, C.N., El-Sayed, F.G., Greeson, G.W. Erb, L., Petris, M.J., Miller, D.C., Sun, G.Y., Weisman, G.A., 2014. Loss of P2Y, nucleotide receptors enhances early pathology in the TgCRND8 mouse model of Alzheimer's disease. Mol. Neurobiol. 49, 1031-1042.

Amadio, S., Parisi, C., Montilli, C., Carrubba, A.S., Apolloni, S., Volonte, C., 2014 P2Y(12) receptor on the verge of a neuroinflammatory breakdown. Mediat. Inflamm. 2014, 975849.

Avendano, B.C., Montero, T.D., Chavez, C.E., von Bernhardi, R., Orellana, J.A., 2015 Jun 19. Prenatal exposure to inflammatory conditions increases $C \times 43$ and Panx1 unopposed channel opening and activation of astrocytes in the offspring effect on neuronal survival. Glia. http://dx.doi.org/10.1002/glia.22877 [Epub ahead of print].

Basso, A.M., Bratcher, N.A., Harris, R.R., Jarvis, M.F., Decker, M.W., Rueter, L.E., 2009 Behavioral profile of P2X7 receptor knockout mice in animal models of depression and anxiety: relevance for neuropsychiatric disorders. Behav. Brain Res. 198, 83-90.

Bender, A.S., Hertz, L., 1986. Similarities of adenosine uptake systems in astrocytes and neurons in primary cultures. Neurochem. Res. 11, 1507-1524.

Bernier, L.P., 2012. Purinergic regulation of inflammasome activation after central nervous system injury. J. Gen. Physiol. 140, 571-575.

Bhattacharya, A., Wang, Q., Ao, H., Shoblock, J.R., Lord, B., Aluisio, L., Fraser, I., Nepomuceno, D., Neff, R.A., Welty, N., Lovenberg, T.W., Bonaventure, P., Wickenden, A.D., Letavic, M.A., 2013. Pharmacological characterization of a novel centrally permeable P2X7 receptor antagonist: JNJ-47965567. Br. J. Pharmacol. 170, 624-640.

Bianco, F., Fumagalli, M., Pravettoni, E., D'Ambrosi, N., Volonte, C., Matteoli, M., Abbracchio, M.P., Verderio, C., 2005. Pathophysiological roles of extracellular nucleotides in glial cells: differential expression of purinergic receptors in resting and activated microglia. Brain Res. Brain Res. Rev. 48, 144-156.

Boison, D., 2008. Astrogliosis and adenosine kinase: a glial basis of epilepsy. Future Neurol. 3, 221-224.

Boison, D., 2012. Adenosine dysfunction in epilepsy. Glia 60, 1234-1243.

Boucher, A.A., Arnold, J.C., Hunt, G.E., Spiro, A., Spencer, J., Brown, C., McGregor, I.S. Bennett, M.R., Kassiou, M., 2011. Resilience and reduced c-Fos expression in P2X7 receptor knockout mice exposed to repeated forced swim test. Neuroscience 189, 170-177.

Brambilla, R., Cottini, L., Fumagalli, M., Ceruti, S., Abbracchio, M.P., 2003. Blockade of A2A adenosine receptors prevents basic fibroblast growth factor-induced reactive astrogliosis in rat striatal primary astrocytes. Glia 43, 190-194.

Brietzke, E., Stabellini, R., Grassi-Oliveira, R., Lafer, B., 2011. Cytokines in bipolar disorder: recent findings, deleterious effects but promise for future therapeutics. CNS Spectr. 16, 157-168.

Browne, S.E., 2013. When too much ATP is a bad thing: a pivotal role for P2X7 receptors in motor neuron degeneration. J. Neurochem. 126, 301-304.

Burnstock, G., 2008. Purinergic signalling and disorders of the central nervous system. Nat. Rev. Drug Discov. 7, 575-590.

Burnstock, G., 2015 Jun 6. An introduction to the roles of purinergic signalling in neurodegeneration, neuroprotection and neuroregeneration. Neuropharmacology. http://dx.doi.org/10.1016/j.neuropharm.2015.05.031 pii: S00283908(15)00212-9. [Epub ahead of print]. 
Burnstock, G., Knight, G.E., 2004. Cellular distribution and functions of P2 receptor subtypes in different systems. Int. Rev. Cytol. 240, 31-304.

Cao, X., Li, L.P., Wang, Q., Wu, Q., Hu, H.H., Zhang, M., Fang, Y.Y., Zhang, J., Li, S.J. Xiong, W.C., Yan, H.C., Gao, Y.B., Liu, J.H., Li, X.W., Sun, L.R., Zeng, Y.N., Zhu, X.H. Gao, T.M., 2013. Astrocyte-derived ATP modulates depressive-like behaviors Nat. Med. 19, 773-777.

Carson, M.J., Doose, J.M., Melchior, B., Schmid, C.D., Ploix, C.C., 2006. CNS immune privilege: hiding in plain sight. Immunol. Rev. 213, 48-65.

Catanzaro, J.M., Hueston, C.M., Deak, M.M., Deak, T., 2014. The impact of the P2X7 receptor antagonist A-804598 on neuroimmune and behavioral consequences of stress. Behav. Pharmacol. 25, 582-598.

Cavaliere, F., Florenzano, F., Amadio, S., Fusco, F.R., Viscomi, M.T., D'Ambrosi, N., Vacca, F. Sancesario, G., Bernardi, G., Molinari, M., Volonte, C., 2003. Up-regulation of P2X2, P2X4 receptor and ischemic cell death: prevention by P2 antagonists. Neuroscience 120, 85-98.

Celsus, A., 1478. De Medicinia. Florence.

Chen, J.F., Lee, C.F., Chern, Y., 2014. Adenosine receptor neurobiology: overview. Int Rev. Neurobiol. 119, 1-49.

Chiu, G.S., Darmody, P.T., Walsh, J.P., Moon, M.L., Kwakwa, K.A., Bray, J.K. McCusker, R.H., Freund, G.G., 2014. Adenosine through the A2A adenosine receptor increases IL-1beta in the brain contributing to anxiety. Brain Behav. Immun. 41, 218-231.

Choi, H.B., Ryu, J.K., Kim, S.U., McLarnon, J.G., 2007. Modulation of the purinergic P2X7 receptor attenuates lipopolysaccharide-mediated microglial activation and neuronal damage in inflamed brain. J. Neurosci. 27, 4957-4968.

Choi, I.Y., Lee, J.C., Ju, C., Hwang, S., Cho, G.S., Lee, H.W., Choi, W.J., Jeong, L.S., Kim, W.K., 2011. A3 adenosine receptor agonist reduces brain ischemic injury and inhibits inflammatory cell migration in rats. Am. J. Pathol. 179, 2042-2052.

Coddou, C., Yan, Z., Obsil, T., Huidobro-Toro, J.P., Stojilkovic, S.S., 2011. Activation and regulation of purinergic P2X receptor channels. Pharmacol. Rev, 63, 641-683.

Communi, D., Robaye, B., Boeynaems, J.M., 1999. Pharmacological characterization of the human P2Y11 receptor. Br. J. Pharmacol. 128, 1199-1206.

Compan, V., Ulmann, L., Stelmashenko, O., Chemin, J., Chaumont, S., Rassendren, F. 2012. P2X2 and P2X5 subunits define a new heteromeric receptor with P2X7like properties. J. Neurosci. 32, 4284-4296.

Csolle, C., Ando, R.D., Kittel, A., Goloncser, F., Baranyi, M., Soproni, K., Zelena, D. Haller, J., Nemeth, T., Mocsai, A., Sperlagh, B., 2013a. The absence of P2X7 receptors (P2rx7) on non-haematopoietic cells leads to selective alteration in mood-related behaviour with dysregulated gene expression and stress reactivity in mice. Int. J. Neuropsychopharmacol. 16, 213-233.

Csolle, C., Baranyi, M., Zsilla, G., Kittel, A., Goloncser, F., Illes, P., Papp, E., Vizi, E.S., Sperlagh, B., 2013b. Neurochemical changes in the mouse Hippocampus underlying the antidepressant effect of genetic deletion of P2X7 receptors. PLoS One 8, e66547.

Csolle, C., Sperlagh, B., 2010. Peripheral origin of IL-1beta production in the rodent hippocampus under in vivo systemic bacterial lipopolysaccharide (LPS) challenge and its regulation by P2X(7) receptors. J. Neuroimmunol. 219, 38-46.

Dahl, G., Keane, R.W., 2012. Pannexin: from discovery to bedside in $11 \pm 4$ years? Brain Res. 1487, 150-159.

de Rivero Vaccari, J.P., Bastien, D., Yurcisin, G., Pineau, I., Dietrich, W.D., De Koninck, Y, Keane, R.W. Lacroix, S., 2012, P2X4 receptors influence inflammasome activation after spinal cord injury. J. Neurosci. 32, 3058-3066.

de Rivero Vaccari, J.P., Lotocki, G., Marcillo, A.E., Dietrich, W.D., Keane, R.W., 2008 A molecular platform in neurons regulates inflammation after spinal cord injury. J. Neurosci. 28, 3404-3414.

Deplano, S., Cook, H.T., Russell, R., Franchi, L., Schneiter, S., Bhangal, G., Unwin, R.J. Pusey, C.D., Tam, F.W., Behmoaras, J., 2013. P2X7 receptor-mediated Nlrp3 inflammasome activation is a genetic determinant of macrophage-dependent crescentic glomerulonephritis. J. Leukoc. Biol. 93, 127-134.

Di Virgilio, F., Ceruti, S., Bramanti, P., Abbracchio, M.P., 2009. Purinergic signalling in inflammation of the central nervous system. Trends Neurosci. 32, 79-87.

Diaz-Hernandez, J.I., Gomez-Villafuertes, R., Leon-Otegui, M., Hontecillas-Prieto, L., Del Puerto, A., Trejo, J.L., Lucas, J.J., Garrido, J.J., Gualix, J., Miras-Portugal, M.T. Diaz-Hernandez, M., 2012. In vivo P2X7 inhibition reduces amyloid plaques in Alzheimer's disease through GSK3beta and secretases. Neurobiol. Aging 33, 1816-1828.

El Yacoubi, M., Costentin, J., Vaugeois, J.M., 2003. Adenosine A2A receptors and depression. Neurology 61, S82-S87.

Engel, T. Jimenez-Pacheco, A., Miras-Portugal, M.T., Diaz-Hernandez, M. Henshall, D.C., 2012. P2X7 receptor in epilepsy; role in pathophysiology and potential targeting for seizure control. Int. J. Physiol. Pathophysiol. Pharmacol. 4 174-187.

Erb, L., Cao, C., Ajit, D., Weisman, G.A., 2015. P2Y receptors in Alzheimer's disease Biol. Cell 107, 1-21.

Eyo, U.B., Gu, N., De, S., Dong, H., Richardson, J.R., Wu, L.J., 2015. Modulation of microglial process convergence toward neuronal dendrites by extracellular calcium. J. Neurosci. 35, 2417-2422.

Eyo, U.B., Peng, J., Swiatkowski, P., Mukherjee, A., Bispo, A., Wu, L.J., 2014. Neuronal hyperactivity recruits microglial processes via neuronal NMDA receptors an microglial P2Y12 receptors after status epilepticus. J. Neurosci. 34 $10528-10540$

Fedele, D.E., Gouder, N., Guttinger, M., Gabernet, L., Scheurer, L., Rulicke, T., Crestani, F., Boison, D., 2005. Astrogliosis in epilepsy leads to overexpression of adenosine kinase, resulting in seizure aggravation. Brain 128, 2383-2395.

Ferrari, D., Chiozzi, P., Falzoni, S., Dal Susino, M., Melchiorri, L., Baricordi, O.R., Di
Virgilio, F., 1997. Extracellular ATP triggers IL-1 beta release by activating the purinergic P2Z receptor of human macrophages. J. Immunol. 159, 1451-1458.

Ferrari, D., Pizzirani, C. Adinolfi, E., Lemoli, R.M., Curti, A., Idzko, M., Panther, E., Di Virgilio, F., 2006. The P2X7 receptor: a key player in IL-1 processing and release. J. Immunol. 176, 3877-3883.

Fiebich, B.L., Akter, S., Akundi, R.S., 2014. The two-hit hypothesis for neuroinflammation: role of exogenous ATP in modulating inflammation in the brain. Front. Cell Neurosci. 8, 260.

Fiebich, B.L., Biber, K., Lieb, K., van Calker, D., Berger, M., Bauer, J. GebickeHaerter, P.J., 1996. Cyclooxygenase-2 expression in rat microglia is induced by adenosine A2a-receptors. Glia 18, 152-160.

Florenzano, F., Viscomi, M.T., Cavaliere, F., Volonte, C., Molinari, M., 2002. Cerebellar lesion up-regulates P2X1 and P2X2 purinergic receptors in precerebellar nuclei. Neuroscience 115, 425-434.

Frank-Cannon, T.C., Alto, L.T., McAlpine, F.E., Tansey, M.G., 2009. Does neuroinflammation fan the flame in neurodegenerative diseases? Mol. Neurodegener. 4, 47.

Franke, H., Krugel, U., Grosche, J., Heine, C., Hartig, W., Allgaier, C., Illes, P., 2004. P2Y receptor expression on astrocytes in the nucleus accumbens of rats. Neuroscience 127, 431-441.

Fredholm, B.B., Chern, Y., Franco, R., Sitkovsky, M., 2007. Aspects of the general biology of adenosine A2A signaling. Prog. Neurobiol. 83, 263-276.

Fujita, T., Tozaki-Saitoh, H., Inoue, K., 2009. P2Y1 receptor signaling enhances neuroprotection by astrocytes against oxidative stress via IL-6 release in hippocampal cultures. Glia 57, 244-257.

Fumagalli, M., Brambilla, R., D'Ambrosi, N., Volonte, C., Matteoli, M., Verderio, C., Abbracchio, M.P., 2003. Nucleotide-mediated calcium signaling in rat cortical astrocytes: role of P2X and P2Y receptors. Glia 43, 218-203.

Gandelman, M., Peluffo, H., Beckman, J.S., Cassina, P., Barbeito, L., 2010. Extracellular ATP and the P2X7 receptor in astrocyte-mediated motor neuron death: implications for amyotrophic lateral sclerosis. J. Neuroinflammation 7, 33.

Gelosa, P., Lecca, D., Fumagalli, M., Wypych, D., Pignieri, A., Cimino, M., Verderio, C., Enerback, M., Nikookhesal, E., Tremoli, E., Abbracchio, M.P., Sironi, L., 2014. Microglia is a key player in the reduction of stroke damage promoted by the new antithrombotic agent ticagrelor. J. Cereb. Blood Flow Metab. 34, 979-988.

Gendelman, H.E., 2002. Neural immunity: friend or foe? J. Neurovirol. 8, 474-479.

Gross, O., Thomas, C.J., Guarda, G., Tschopp, J., 2011. The inflammasome: an integrated view. Immunol. Rev. 243, 136-151.

Gu, J.G., MacDermott, A.B., 1997. Activation of ATP P2X receptors elicits glutamate release from sensory neuron synapses. Nature 389, 749-753.

Gubert, C., Fries, G.R. Pfaffenseller, B., Ferrari, P., Coutinho-Silva, R., Morrone, F.B., Kapczinski, F., Battastini, A.M., 2014 Dec 11. Role of P2X7 receptor in an animal model of mania induced by D-amphetamine. Mol. Neurobiol. [Epub ahead of print].

Gulbransen, B.D., Bashashati, M., Hirota, S.A., Gui, X., Roberts, J.A., MacDonald, J.A., Muruve, D.A., McKay, D.M., Beck, P.L., Mawe, G.M., Thompson, R.J., Sharkey, K.A., 2012. Activation of neuronal P2X7 receptor-pannexin-1 mediates death of enteric neurons during colitis. Nat. Med. 18, 600-604.

Gyoneva, S., Shapiro, L., Lazo, C., Garnier-Amblard, E., Smith, Y., Miller, G.W., Traynelis, S.F., 2014. Adenosine A2A receptor antagonism reverses inflammation-induced impairment of microglial process extension in a model of Parkinson's disease. Neurobiol. Dis. 67, 191-202.

Hansen, T., Jakobsen, K.D., Fenger, M., Nielsen, J., Krane, K., Fink-Jensen, A., Lublin, H., Ullum, H., Timm, S., Wang, A.G., Jorgensen, N.R., Werge, T., 2008. Variation in the purinergic P2RX(7) receptor gene and schizophrenia. Schizophr. Res. 104, 146-152.

Hasko, G., Pacher, P., 2008. A2A receptors in inflammation and injury: lessons learned from transgenic animals. J. Leukoc. Biol. 83, 447-455.

Hasko, G., Pacher, P., Vizi, E.S., Illes, P., 2005. Adenosine receptor signaling in the brain immune system. Trends Pharmacol. Sci. 26, 511-516.

Hauss-Wegrzyniak, B., Lynch, M.A., Vraniak, P.D., Wenk, G.L., 2002. Chronic brain inflammation results in cell loss in the entorhinal cortex and impaired LTP in perforant path-granule cell synapses. Exp. Neurol. 176, 336-341.

Haynes, S.E., Hollopeter, G., Yang, G., Kurpius, D., Dailey, M.E., Gan, W.B., Julius, D., 2006. The P2Y12 receptor regulates microglial activation by extracellular nucleotides. Nat. Neurosci. 9, 1512-1519.

He, Y., Franchi, L., Nunez, G., 2013. TLR agonists stimulate Nlrp3-dependent IL-1beta production independently of the purinergic P2X7 receptor in dendritic cells and in vivo. J. Immunol. 190, 334-339.

Hindley, S., Herman, M.A., Rathbone, M.P., 1994. Stimulation of reactive astrogliosis in vivo by extracellular adenosine diphosphate or an adenosine A2 receptor agonist. J. Neurosci. Res. 38, 399-406.

Hines, D.J., Schmitt, L.I., Hines, R.M., Moss, S.J., Haydon, P.G., 2013. Antidepressant effects of sleep deprivation require astrocyte-dependent adenosine mediated signaling. Transl. Psychiatry 3, e212.

Hodgson, R.A., Bertorelli, R., Varty, G.B., Lachowicz, J.E., Forlani, A., Fredduzzi, S. Cohen-Williams, M.E., Higgins, G.A., Impagnatiello, F., Nicolussi, E., Parra, L.E., Foster, C., Zhai, Y., Neustadt, B.R., Stamford, A.W., Parker, E.M., Reggiani, A., Hunter, J.C., 2009. Characterization of the potent and highly selective A2A receptor antagonists preladenant and SCH 412348 [7-[2-[4-2,4-difluorophenyl]1-piperazinyl]ethyl]-2-(2-furanyl)-7H-pyrazolo[4,3-e ][1,2,4]triazolo[1,5-c]pyrimidin-5-amine] in rodent models of movement disorders and depression. J. Pharmacol. Exp. Ther. 330, 294-303.

Inoue, K., 2007. UDP facilitates microglial phagocytosis through P2Y6 receptors. Cell Adhes. Migr. 1, 131-132. 
Iwata, M., Ota, K.T., Duman, R.S., 2013. The inflammasome: pathways linking psychological stress, depression, and systemic illnesses. Brain Behav. Immun. 31, 105-114.

Jacobson, K.A., Paoletta, S., Katritch, V., Wu, B., Gao, Z.G., Zhao, Q., Stevens, R.C., Kiselev, E., 2015. Nucleotides acting at P2Y receptors: connecting structure and function. Mol. Pharmacol. 88, 220-230.

Janelidze, S., Mattei, D., Westrin, A., Traskman-Bendz, L., Brundin, L., 2011. Cytokine levels in the blood may distinguish suicide attempters from depressed patients. Brain Behav. Immun. 25, 335-339.

Jokela, T.A., Karna, R., Makkonen, K.M., Laitinen, J.T., Tammi, R.H., Tammi, M.I., 2014. Extracellular UDP-glucose activates P2Y14 receptor and induces signal transducer and activator of transcription 3 (STAT3) Tyr705 phosphorylation and binding to hyaluronan synthase 2 (HAS2) promoter, stimulating hyaluronan synthesis of keratinocytes. J. Biol. Chem. 289, 18569-18581.

Kaster, M.P., Budni, J., Binfare, R.W., Santos, A.R., Rodrigues, A.L., 2007a. The inhibition of different types of potassium channels underlies the antidepressantlike effect of adenosine in the mouse forced swimming test. Prog. Neuropsychopharmacol. Biol. Psychiatry 31, 690-696.

Kaster, M.P., Budni, J., Santos, A.R., Rodrigues, A.L., 2007b. Pharmacological evidence for the involvement of the opioid system in the antidepressant-like effect of adenosine in the mouse forced swimming test. Eur. J. Pharmacol. 576, 91-98.

Kaster, M.P., Rosa, A.O., Rosso, M.M., Goulart, E.C., Santos, A.R., Rodrigues, A.L., 2004. Adenosine administration produces an antidepressant-like effect in mice: evidence for the involvement of A1 and A2A receptors. Neurosci. Lett. 355, 21-24.

Kim, H.J., Ajit, D., Peterson, T.S., Wang, Y., Camden, J.M., Gibson Wood, W., Sun, G.Y., Erb, L., Petris, M., Weisman, G.A., 2012. Nucleotides released from Abeta(1)((4)(2) -treated microglial cells increase cell migration and Abeta(1)(-)(4)(2) uptake through P2Y(2) receptor activation. J. Neurochem. 121, 228-238.

Koizumi, S., Shigemoto-Mogami, Y., Nasu-Tada, K., Shinozaki, Y., Ohsawa, K., Tsuda, M., Joshi, B.V., Jacobson, K.A., Kohsaka, S., Inoue, K., 2007. UDP acting at P2Y6 receptors is a mediator of microglial phagocytosis. Nature 446, 1091-1095.

Kongsui, R., Beynon, S.B., Johnson, S.J., Mayhew, J., Kuter, P., Nilsson, M., Walker, F.R., 2014. Chronic stress induces prolonged suppression of the P2X7 receptor within multiple regions of the hippocampus: a cumulative threshold spectra analysis. Brain Behav. Immun. 42, 69-80.

Koscso, B., Csoka, B., Selmeczy, Z., Himer, L., Pacher, P., Virag, L., Hasko, G., 2012. Adenosine augments IL-10 production by microglial cells through an A2B adenosine receptor-mediated process. J. Immunol. 188, 445-453.

Kuan, Y.H., Shih, H.C., Tang, S.C., Jeng, J.S., Shyu, B.C., 2015. Targeting P(2)X(7) receptor for the treatment of central post-stroke pain in a rodent model. Neurobiol. Dis. 78, 134-145.

Latini, S., Pedata, F., 2001. Adenosine in the central nervous system: release mechanisms and extracellular concentrations. J. Neurochem. 79, 463-484.

Liang, D., Zuo, A., Shao, H., Chen, M., Kaplan, H.J., Sun, D., 2014. Anti-inflammatory or proinflammatory effect of an adenosine receptor agonist on the Th17 autoimmune response is inflammatory environment-dependent. J. Immunol. 193, $5498-5505$.

Lister, M.F., Sharkey, J., Sawatzky, D.A., Hodgkiss, J.P., Davidson, D.J., Rossi, A.G., Finlayson, K., 2007. The role of the purinergic P2X7 receptor in inflammation. J. Inflamm. (Lond.) $4,5$.

Liu, Y., Ho, R.C., Mak, A., 2012. Interleukin (IL)-6, tumour necrosis factor alpha (TNFalpha) and soluble interleukin-2 receptors (sIL-2R) are elevated in patients with major depressive disorder: a meta-analysis and meta-regression. J. Affect Disord. 139, 230-239.

Liverani, E., Kilpatrick, L.E., Tsygankov, A.Y., Kunapuli, S.P., 2014a. The role of P2Y(1)(2) receptor and activated platelets during inflammation. Curr. Drug Targ. $15,720-728$.

Liverani, E., Rico, M.C., Yaratha, L., Tsygankov, A.Y., Kilpatrick, L.E., Kunapuli, S.P., 2014b. LPS-induced systemic inflammation is more severe in P2Y12 null mice. J. Leukoc. Biol. 95, 313-323.

Lord, B., Aluisio, L., Shoblock, J.R., Neff, R.A., Varlinskaya, E.I., Ceusters, M. Lovenberg, T.W., Carruthers, N., Bonaventure, P., Letavic, M.A., Deak, T. Drinkenburg, W., Bhattacharya, A., 2014. Pharmacology of a novel central nervous system-penetrant P2X7 antagonist JNJ-42253432. J. Pharmacol. Exp. Ther. 351, 628-641.

Luongo, L., Guida, F., Imperatore, R., Napolitano, F., Gatta, L., Cristino, L., Giordano, C., Siniscalco, D., Di Marzo, V., Bellini, G., Petrelli, R., Cappellacci, L., Usiello, A., de Novellis, V., Rossi, F. Maione, S., 2014. The A1 adenosine receptor as a new player in microglia physiology. Glia 62, 122-132.

Ma, M., Ren, Q., Zhang, J.C., Hashimoto, K., 2014. Effects of brilliant blue g on serum tumor necrosis factor-alpha levels and depression-like behavior in mice after lipopolysaccharide administration. Clin. Psychopharmacol. Neurosci. 12, 31-36.

Magni, G., Merli, D., Verderio, C., Abbracchio, M.P., Ceruti, S., 2015. P2Y2 receptor antagonists as anti-allodynic agents in acute and sub-chronic trigeminal sensitization: role of satellite glial cells. Glia 63, 1256-1269.

Marcellino, D., Suarez-Boomgaard, D., Sanchez-Reina, M.D., Aguirre, J.A., Yoshitake, T., Yoshitake, S., Hagman, B., Kehr, J., Agnati, L.F., Fuxe, K., Rivera, A., 2010. On the role of $P 2 X(7)$ receptors in dopamine nerve cell degeneration in a rat model of Parkinson's disease: studies with the P2X(7) receptor antagonist A438079. J. Neural Transm. 117, 681-687.

Martinon, F., Burns, K., Tschopp, J., 2002. The inflammasome: a molecular platform triggering activation of inflammatory caspases and processing of proIL-beta. Mol. Cell 10, 417-426.

Matos, M., Shen, H.Y., Augusto, E., Wang, Y., Wei, C.J., Wang, Y.T., Agostinho, P.,
Boison, D., Cunha, R.A., Chen, J.F., 2015 Feb 27. Deletion of adenosine a receptors from astrocytes disrupts glutamate homeostasis leading to psychomotor and cognitive impairment: relevance to schizophrenia. Biol. Psychiatry. http:/ dx.doi.org/10.1016/j.biopsych.2015.02.026 pii: S0006-3223(15)00151-1. [Epub ahead of print].

Melani, A., Corti, F. Stephan, H., Muller, C.E., Donati, C., Bruni, P. Vannucchi, M.G. Pedata, F., 2012. Ecto-ATPase inhibition: ATP and adenosine release unde physiological and ischemic in vivo conditions in the rat striatum. Exp. Neurol. 233, 193-204.

Meyer, U., 2013. Developmental neuroinflammation and schizophrenia. Prog. Neuropsychopharmacol. Biol. Psychiatry 42, 20-34.

Miller, B.J., Buckley, P., Seabolt, W., Mellor, A., Kirkpatrick, B., 2011. Meta-analysis of cytokine alterations in schizophrenia: clinical status and antipsychotic effects. Biol. Psychiatry 70, 663-671.

Mingam, R., De Smedt, V., Amedee, T., Bluthe, R.M., Kelley, K.W., Dantzer, R., Laye, S., 2008. In vitro and in vivo evidence for a role of the P2X7 receptor in the release of IL-1 beta in the murine brain. Brain Behav. Immun. 22, 234-244.

Monif, M., Reid, C.A., Powell, K.L., Smart, M.L., Williams, D.A., 2009. The P2X7 receptor drives microglial activation and proliferation: a trophic role for P2X7R pore. J. Neurosci. 29, 3781-3791.

Munkholm, K., Brauner, J.V., Kessing, L.V., Vinberg, M., 2013. Cytokines in bipolar disorder vs. healthy control subjects: a systematic review and meta-analysis. J. Psychiatr. Res. 47, 1119-1133.

Munoz-Planillo, R., Kuffa, P., Martinez-Colon, G., Smith, B.L., Rajendiran, T.M., Nunez, G., 2013. K(+) efflux is the common trigger of NLRP3 inflammasome activation by bacterial toxins and particulate matter. Immunity 38, 1142-1153.

Muto, J., Lee, H., Lee, H., Uwaya, A., Park, J., Nakajima, S., Nagata, K., Ohno, M. Ohsawa, I., Mikami, T., 2014. Oral administration of inosine produces antidepressant-like effects in mice. Sci. Rep. 4, 4199.

Najjar, S., Pearlman, D.M., Alper, K., Najjar, A., Devinsky, O., 2013. Neuroinflammation and psychiatric illness. J. Neuroinflammation 10, 43.

Nathan, C., 2002. Points of control in inflammation. Nature 420, 846-852.

Naviaux, J.C., Schuchbauer, M.A., Li, K., Wang, L., Risbrough, V.B., Powell, S.B., Naviaux, R.K., 2014. Reversal of autism-like behaviors and metabolism in adult mice with single-dose antipurinergic therapy. Transl. Psychiatry 4, e400.

Naviaux, J.C., Wang, L., Li, K., Bright, A.T., Alaynick, W.A., Williams, K.R., Powell, S.B., Naviaux, R.K., 2015. Antipurinergic therapy corrects the autism-like features in the Fragile X (Fmr1 knockout) mouse model. Mol. Autism 6, 1.

Naviaux, R.K., Zolkipli, Z., Wang, L., Nakayama, T., Naviaux, J.C., Le, T.P. Schuchbauer, M.A., Rogac, M., Tang, Q., Dugan, L.L., Powell, S.B., 2013. Antipurinergic therapy corrects the autism-like features in the poly(IC) mouse model. PLoS One 8, e57380.

North, R.A., 2002. Molecular physiology of P2X receptors. Physiol. Rev. 82 $1013-1067$

North, R.A., Jarvis, M.F., 2013. P2X receptors as drug targets. Mol. Pharmacol. 83, 759-769.

O'Callaghan, J.P., Sriram, K., Miller, D.B., 2008. Defining “neuroinflammation”. Ann. N. Y. Acad. Sci. 1139, 318-330.

Ohsawa, K., Sanagi, T., Nakamura, Y., Suzuki, E., Inoue, K., Kohsaka, S., 2012. Adenosine A3 receptor is involved in ADP-induced microglial process extension and migration. J. Neurochem. 121, 217-227.

Orellana, J.A., Moraga-Amaro, R., Diaz-Galarce, R., Rojas, S., Maturana, C.J., Stehberg, J., Saez, J.C., 2015. Restraint stress increases hemichannel activity in hippocampal glial cells and neurons. Front. Cell. Neurosci. 9, 102.

Orr, A.G., Orr, A.L., Li, X.J., Gross, R.E., Traynelis, S.F., 2009. Adenosine A(2A) receptor mediates microglial process retraction. Nat. Neurosci. 12, 872-878.

Panenka, W., Jijon, H., Herx, L.M., Armstrong, J.N., Feighan, D., Wei, T., Yong, V.W. Ransohoff, R.M., MacVicar, B.A., 2001. P2X7-like receptor activation in astrocytes increases chemokine monocyte chemoattractant protein-1 expression via mitogen-activated protein kinase. J. Neurosci. 21, 7135-7142.

Pechlivanova, D.M., Tchekalarova, J.D., Alova, L.H., Petkov, V.V., Nikolov, R.P. Yakimova, K.S., 2012. Effect of long-term caffeine administration on depressivelike behavior in rats exposed to chronic unpredictable stress. Behav. Pharmacol. 23, 339-347.

Pedata, F., Pugliese, A.M., Coppi, E., Dettori, I., Maraula, G., Cellai, L., Melani, A., 2014 Adenosine A2A receptors modulate acute injury and neuroinflammation in brain ischemia. Mediat. Inflamm. 2014, 805198

Pelegrin, P., Barroso-Gutierrez, C., Surprenant, A., 2008. P2X7 receptor differentially couples to distinct release pathways for IL-1beta in mouse macrophage. J. Immunol. 180, 7147-7157.

Pelegrin, P., Surprenant, A., 2006. Pannexin-1 mediates large pore formation and interleukin-1beta release by the ATP-gated P2X7 receptor. EMBO J. 25 5071-5082.

Peng, L., Huang, R., Yu, A.C., Fung, K.Y., Rathbone, M.P., Hertz, L., 2005. Nucleoside transporter expression and function in cultured mouse astrocytes. Glia 52, 25-35.

Pereira, V.S., Casarotto, P.C., Hiroaki-Sato, V.A., Sartim, A.G., Guimaraes, F.S. Joca, S.R., 2013. Antidepressant- and anticompulsive-like effects of purinergic receptor blockade: involvement of nitric oxide. Eur. Neuropsychopharmacol. 23, $1769-1778$.

Perez-Sen, R., Queipo, M.J., Morente, V., Ortega, F., Delicado, E.G., Miras Portugal, M.T., 2015. Neuroprotection mediated by P2Y13 nucleotide receptors in neurons. Comput. Struct. Biotechnol. J. 13, 160-168.

Qu, Y., Misaghi, S., Newton, K., Gilmour, L.L., Louie, S., Cupp, J.E., Dubyak, G.R., Hackos, D., Dixit, V.M., 2011. Pannexin-1 is required for ATP release during 
apoptosis but not for inflammasome activation. J. Immunol. 186, 6553-6561.

Rebola, N., Simoes, A.P. Canas, P.M., Tome, A.R., Andrade, G.M., Barry, C.E., Agostinho, P.M., Lynch, M.A., Cunha, R.A., 2011. Adenosine A2A receptors contro neuroinflammation and consequent hippocampal neuronal dysfunction. J. Neurochem. 117, 100-111.

Reece, T.B., Okonkwo, D.O., Ellman, P.I., Warren, P.S., Smith, R.L., Hawkins, A.S Linden, J., Kron, I.L., Tribble, C.G., Kern, J.A., 2004. The evolution of ischemic spinal cord injury in function, cytoarchitecture, and inflammation and the ef fects of adenosine A2A receptor activation. J. Thorac. Cardiovasc. Surg. 128, 925-932.

Roth, T.L., Nayak, D., Atanasijevic, T., Koretsky, A.P., Latour, L.L., McGavern, D.B., 2014 Transcranial amelioration of inflammation and cell death following brain injury. Nature 505, 223-228.

Rubio-Araiz, A., Perez-Hernandez, M., Urrutia, A., Porcu, F., Borcel, E., GutierrezLopez, M.D., O'Shea, E., Colado, M.I., 2014. 3,4-Methylenedioxymethamphetamine (MDMA, ecstasy) disrupts blood-brain barrier integrity through a mechanism involving P2X7 receptors. Int. J. Neuropsychopharmacol. 17, 1243-1255.

Schulte, G., Fredholm, B.B., 2003. Signalling from adenosine receptors to mitogenactivated protein kinases. Cell. Signal. 15, 813-827.

Schwab, J.M., Guo, L., Schluesener, H.J., 2005. Spinal cord injury induces early and persistent lesional P2X4 receptor expression. J. Neuroimmunol. 163, 185-189.

Sharp, A.J., Polak, P.E., Simonini, V., Lin, S.X., Richardson, J.C., Bongarzone, E.R., Feinstein, D.L., 2008. P2x7 deficiency suppresses development of experimental autoimmune encephalomyelitis. J. Neuroinflammation 5, 33.

Silverman, W.R., de Rivero Vaccari, J.P., Locovei, S., Qiu, F., Carlsson, S.K., Scemes, E., Keane, R.W., Dahl, G., 2009. The pannexin 1 channel activates the inflammasome in neurons and astrocytes. J. Biol. Chem. 284, 18143-18151.

Streit, W.J., Mrak, R.E., Griffin, W.S., 2004. Microglia and neuroinflammation: a pathological perspective. J. Neuroinflammation 1,14.

Studer, F.E., Fedele, D.E., Marowsky, A., Schwerdel, C., Wernli, K., Vogt, K. Fritschy, J.M., Boison, D., 2006. Shift of adenosine kinase expression from neurons to astrocytes during postnatal development suggests dual functionality of the enzyme. Neuroscience 142, 125-137.

Surprenant, A., Rassendren, F., Kawashima, E., North, R.A., Buell, G., 1996. The cytolytic P2Z receptor for extracellular ATP identified as a P2X receptor (P2X7). Science 272, 735-738.

Tsuda, M., Shigemoto-Mogami, Y., Koizumi, S., Mizokoshi, A., Kohsaka, S. Salter, M.W., Inoue, K., 2003. P2X4 receptors induced in spinal microglia gate tactile allodynia after nerve injury. Nature 424, 778-783.

Ulmann, L. Hatcher, J.P. Hughes, J.P., Chaumont, S., Green, P.J., Conquet, F, Buell, G.N., Reeve, A.J., Chessell, I.P., Rassendren, F., 2008. Up-regulation of P2X4 receptors in spinal microglia after peripheral nerve injury mediates BDNF release and neuropathic pain. J. Neurosci. 28, 11263-11268.

Ulmann, L., Hirbec, H., Rassendren, F., 2010. P2X4 receptors mediate PGE2 release by tissue-resident macrophages and initiate inflammatory pain. EMBO J. 29, 2290-2300.

Ursu, D., Ebert, P., Langron, E., Ruble, C., Munsie, L., Zou, W., Fijal, B., Qian, Y.W.,
McNearney, T.A., Mogg, A., Grubisha, O., Merchant, K., Sher, E., 2014. Gain and loss of function of P2X7 receptors: mechanisms, pharmacology and relevance to diabetic neuropathic pain. Mol. Pain 10, 37.

van der Putten, C., Zuiderwijk-Sick, E.A., van Straalen, L., de Geus, E.D., Boven, L.A., Kondova, I., IJzerman, A.P., Bajramovic, J.J., 2009. Differential expression of adenosine A3 receptors controls adenosine A2A receptor-mediated inhibition of TLR responses in microglia. J. Immunol. 182, 7603-7612.

Vaughan, K.R., Stokes, L., Prince, L.R., Marriott, H.M., Meis, S., Kassack, M.U., Bingle, C.D., Sabroe, I., Surprenant, A., Whyte, M.K., 2007. Inhibition of neutrophil apoptosis by ATP is mediated by the P2Y11 receptor. J. Immunol. 179, 8544-8553.

Viscomi, M.T., Florenzano, F., Conversi, D., Bernardi, G., Molinari, M., 2004. Axotomy dependent purinergic and nitrergic co-expression. Neuroscience 123, 393-404.

Vivekanantham, S., Shah, S., Dewji, R., Dewji, A., Khatri, C., Ologunde, R., 2015. Neuroinflammation in Parkinson's disease: role in neurodegeneration and tissue repair. Int. J. Neurosci. 125, 717-725.

Watanabe, H., Gaide, O., Petrilli, V., Martinon, F., Contassot, E., Roques, S., Kummer, J.A., Tschopp, J., French, L.E., 2007. Activation of the IL-1betaprocessing inflammasome is involved in contact hypersensitivity. J. Invest. Dermatol. 127, 1956-1963.

Webster, C.M., Hokari, M., McManus, A., Tang, X.N., Ma, H., Kacimi, R., Yenari, M.A., 2013. Microglial P2Y12 deficiency/inhibition protects against brain ischemia. PLoS One 8, e70927.

Weisman, G.A., Camden, J.M., Peterson, T.S., Ajit, D., Woods, L.T., Erb, L., 2012. P2 receptors for extracellular nucleotides in the central nervous system: role of P2X7 and P2Y(2) receptor interactions in neuroinflammation. Mol. Neurobiol. 46, 96-113.

Wilkinson, S.M., Gunosewoyo, H., Barron, M.L., Boucher, A., McDonnell, M., Turner, P., Morrison, D.E., Bennett, M.R., McGregor, I.S., Rendina, L.M. Kassiou, M., 2014. The first CNS-active carborane: a novel P2X7 receptor antagonist with antidepressant activity. ACS Chem. Neurosci. 5, 335-339.

Wilot, L.C., Bernardi, A., Frozza, R.L., Marques, A.L., Cimarosti, H., Salbego, C., Rocha, E., Battastini, A.M., 2007. Lithium and valproate protect hippocampal slices against ATP-induced cell death. Neurochem. Res. 32, 1539-1546.

Xanthos, D.N., Sandkuhler, J., 2014. Neurogenic neuroinflammation: inflammatory CNS reactions in response to neuronal activity. Nat. Rev. Neurosci. 15, 43-53.

Yamasaki, R., Lu, H., Butovsky, O., Ohno, N., Rietsch, A.M., Cialic, R., Wu, P.M. Doykan, C.E., Lin, J., Cotleur, A.C., Kidd, G., Zorlu, M.M., Sun, N., Hu, W., Liu, L., Lee, J.C., Taylor, S.E., Uehlein, L., Dixon, D., Gu, J., Floruta, C.M., Zhu, M., Charo, I.F., Weiner, H.L., Ransohoff, R.M., 2014. Differential roles of microglia and monocytes in the inflamed central nervous system. J. Exp. Med. 211, 1533-1549.

Yirmiya, R., Goshen, I., 2011. Immune modulation of learning, memory, neural plasticity and neurogenesis. Brain Behav. Immun. 25, 181-213.

Zhang, Z., Artelt, M., Burnet, M., Trautmann, K., Schluesener, H.J., 2006. Lesional accumulation of P2X4 receptor ${ }^{+}$monocytes following experimental traumatic brain injury. Exp. Neurol. 197, 252-257.

Zimmermann, H., 2000. Extracellular metabolism of ATP and other nucleotides. Naunyn Schmiedebergs Arch. Pharmacol. 362, 299-309. 